\title{
STUDIES ON PROTEINS IV. ON THE PREPARATION OF RICE-GLUTELIN.
}

\author{
(Contribution No. 5 from the Laboratory of Nutritional Chemistry, Dept. \\ of Agriculture, Kyoto Imperial University)
}

By

Kinsuke Kondo and Tunetomo HayAshi.

(Received Sept Sth., 1926.)

A. In great probability it is impossible to prepare such a chemically pure single protein as we desire. This point was clucidated by Sörensen's experiments. ${ }^{(1)}$ As is well known, we can find in polished rice besides other constituents four kinds of protein such as albumin, globulin, glutelin and prolamin. We may reasonably assume these proteins occur in the rice itself, as well as in the special protein fractions obtained from it, not as mixtures of proteins, but as their combinations, as Sörensen considers in regard to serum-globulins. Consequently even tho we might isolate a special protein fraction from the natural substance, this fraction could not consist of merely the desired single protein. We state herewith that it is a reasonable question to-day whether the fraction thus obtained is reproduceable or not. Presumably it would be secondary whether pure or not. However we may expect to prepare a well-defined and reproduceable protein. In studying the chemistry of proteins we shall be satisfied at present with such a protein as discussed above.

B. a. Rice-glutelin, as well as other kinds of proteins, capable of change in an alkali-solution, even tho this be not very strong. In preparing the rice-glutelin we may first remove the albumin and globulin from the ricepowder. For this purpose we extract the rice powder with a $10 \% \mathrm{NaCl}$ solution 3 times continuously and then wash out completely till it contains no $\mathrm{NaCl}$.

The residue is mixed with water and then with a $0.05 n \mathrm{NaOH}$ solution by means of dropping in such a manner that the concentration of $\mathrm{NaOH}$ will be under 0.025n. Then the rice-glutelin dissolves into the $\mathrm{NaOH}$ solution. This solution is clarified and freed from starch particles and other ingredients after repeated filtration. Into the clear solution thus obtained a

(1) Comptes-rendus du Lab. Carlsberg 12. (1917)

Zeitschr, physiol. Chem. 103. (1918)

Jour. Amer. Chem. Soc. 47, 457. (1925) 
certain amount of $0.05 \mathrm{n}$ acetic acid is dropped till the glutelin flocculates out as completely as possible. The glutelin precipitate is filtered and washed respectively and then redissolved and reflocculated. Such a procedure is repeated 3 times continuoulsy to make it free from other nitrogenous ingredients, and this was proved experimentally. In this whole treatment about one third of the nitrogenous substance in rice powder is lost.

B. b. We purified our rice-glutelin mineral substance and acetic acid by application of dialysis. The experiments show that the rice-glutelin becomes practically entirely free from any diffusible ingredient, such as mineral matter, in 6 or 7 days. Hence, we can believe that the protein thus purified contains practically no other ingredient. We call it Rice-glutelin No. 1.

B. c. We made our rice-glutelin into anhydrous state with the help of alcohol and ether and determined the amount of nitrogen and its distribution by the usual method.

B. d. It is proved that a $0.5 \mathrm{n} \mathrm{NaCl}$ solution is a more reasonable solvent for removing globulin from the rice powder than a $10 \% \mathrm{NaCl}$ solution, which is used commonly. Hereafter we shall prefer a $0.5 \mathrm{n} \mathrm{NaCl}$ solution in the foregoing preparation of glutelin to any other.

(Sept. 5, 1925)

\section{STUDIES ON PROTEINS V. ON THE POINT OF OPTIMUM FLOCCULATION OF RICE-GLUTELIN.}

(Contribution No. to from the Laboratory of Nutritional Chemistry, Dept. of Agriculture, Kyoto Imperial University).

By

Kinsuke Kondo and Tunetomo Hayashi.

(Received Sept. Sth., 1926)

A. After Michaelis, (1) an iso-electric point of ampholyte difficult of. solution, i. e. casein, falls on the point of an optimum flocculation.

(1) Michaelis :- Biochem. Zeitschr. 47, 250 u. 260. (1912) 